\title{
Program Siaran Interaktif (Talk Back Radio) Sebagai Ruang Publik Masyarakat Untuk Mengembangkan Demokrasi Lokal: Studi Pada Program "Citra Publika" Radio Citra 87,9 FM Kota Malang.
}

\author{
Rochmad Effendy \\ Dosen Ilmu Komunikasi FISIP Universitas Merdeka Malang.
}

\begin{abstract}
As social institution, national press should serve pubic interest by meeting the people's right to know in the form of news which concerns the lives of the people. In addition to that, press is also required to serve public to spare its pace and time for people to express their voices and grievances regarding public issues. Due to its interactivity and hyper-local journalism, radio can perform this well. Talkback radio broadcasts containing interaction between the host broadcaster with the listener expressing their concerns and information on public issues has been able to encourage the process of local democratization. As such "Citra Publika" has been able to encourage citizens not only to exercise social control and take part in debating public concerns but also ask them to give solution the public problems. The research which used a qualitative approach with some informants form Citra FM radio has found that that listeners not only are asked to express their information and concerns but also are invited to provide solutions to these problems. Announcer, then made every effort to contact the relevant parties to confirm the citizen complaint information. But managerial conflict within the radio has made the talkback radio unable to operate optimally. Unfortunately, to make things even worse, the conflict has led to cessation of broadcasting activities.
\end{abstract}

Key Words : Talkback radio, Public Sphere, Interactive Journalism, Democracy

\begin{abstract}
Abstrak
Sebagai lembaga sosial, pers nasional harus memberikan layanan publik kepada khalayak berupa pemberitaan yang menyangkut hajat hidup masyarakat. Pers juga diwajibkan untuk memberikan kesempatan kepada warga untuk bereskpresi. Fungsi pers ini telah mampu diimplementasikan radio. Hal ini mengingat karakter radio yang interaktif dan sarat muatan jurnalistik lokal ini sehingga menjadikannya sebagai ruang publik bagi warga. Talkback radio yang berisikan siaran interaktif antara host penyiar dengan pendengar yang menyampaikan pendapat dan informasi tentang permasalahan publik telah dapat menggiatkan proses demokratisasi. Program "Citra Publika" mampu mendorong partisipasi warga untuk melakukan kontrol sosial. Penelitian yang menggunakan pendekatan kualitatif dengan informan dari pengelola radio menemukan bahwa pendengar yang berinteraksi tidak saja menyampaikan pendapat dan informasi tapi juga diajak untuk memberikan solusi terhadap permasalahan tersebut. Penyiar lantas menghubungi pihak terkait untuk mengkonfirmasi informasi keluhan warga tersebut. Tapi konflik manajerial membuat $\mathrm{K}_{3}$ tidak bisa berlangsung optimal. Konflik yang sama juga melanda Citra FM yang mengakibatkan terhentinya kegiatan siaran.
\end{abstract}

Kata Kunci : Talkback Radio, Ruang Publik, Jurnalisme Interaktif, Demokrasi 


\section{Pendahuluan}

Pers nasional seperti diamanatkan UU No 40 tahun 1999 Tentang Pers berkewajiban untuk melayani kepentingan publik. Pers nasional wajib memenuhi hak rakyat untuk tahu (the people's right to know) dengan memberikan peristiwaperistiwa yang menyangkut hajat hidup masyarakat. Pers juga wajib memenuhi hak masyarakat untuk berekspresi dengan menyediakan ruang dan waktu bagi mereka untuk mengungkap pendapat, gagasan dan informasi yang berkaitan dengan permasalahan publik. Yang dimaksud dengan kepentingan publik (public interest), menurut David Croteau (2001: 36-37) adalah program siaran yang substantif, inovatif dan beragam meski terkadang tidak disukai masyarakat. Program siaran harus berkaitan dengan hal-hal penting yang langsung berkaitan dengan hajat hidup masyarakat, bukan yang mereka sukai. Yang kreatif inovatif yang dapat mendorong warga terlibat aktif untuk diskusi bersama membahas permasalahan publik. Kepentingan publik berarti sebuah keniscayaan yang harus ada dalam sebuah sistem politik demokratis yang berupaya untuk memenuhi setiap kepentingan warga ; 'a necessity in a democratic political system and thus in every citizen's interest' (Dennis McQuail, 1992:23).

Sebagai lembaga sosial dan penyanggah demokrasi keempat, media berfungsi untuk mengontrol perilaku kekuasaan politik penguasa dan kuasa ekonomi pengusaha. Namun sebagai lembaga ekonomi, media juga dikelola untuk melayani kepentingan ekonomi politiknya sendiri. Media tidak dikelola dalam ruang hampa; media dijalankan dengan dorongan dan motivasi untuk melayani kepentingan ekonomi dan politiknya sendiri agar tetap bertahan hidup. Isi media dan realitas media, makanya bukan merupakan pantulan jujur dari realitas sosial tapi adalah konstruksi dan bentukan dari para pekerja media. Kalau demikian adanya maka proses demokratisasi yang merupakan kewajiban etik media untuk memeliharanya akan tersendat-sendat perjalanannya. Untuk itulah diperlukan pillar kelima demokrasi, yakni masyarakat warga yang aktif; ikut terlibat aktif dalam menjaga proses demokrasi. Mereka ini diharapkan akan mampu memilih dan memilah informasi politik, serta memahami dan mengambil peran aktif dalam perdebatan publik serta mampu membuat keputusan rasional berkaitan dengan lingkungan sosial dan politiknya.

Interaktivitas dan sarat muatan lokal memudahkan radio dapat memperluas ruang publik dengan cara menggiatkan warga terlibat aktif dalam diskusi dan perdebatan mengenai isu-isu publik. Hal ini meniscayakan adanya etos dan kultur jurnalisme radio yang kuat. Etos dan kultur jurnalisme, menurut Errol Jonathans (2006:100), radio dapat menyajikan kebutuhan pendengar dengan menyediakan pemberitaan yang aktual lewat opini, talkback radio, interaksi yang selanjutnya akan berdampak terhadap kinerja finansial kepada manajemen radio. Etos jurnalisme ini, lanjut Errol (2006:101) ibarat vitamin atau suplemen makanan kesehatan yang lewat proses waktu yang berkelanjutan akan menyehatkan kinerja manajemen radio. Dengan latar belakang seperti ini tidak heran jika radio selalu lekat dengan perubahan sosial dan proses demokratisasi baik dalam tataran lokal dan nasional. Menjelang runtuhnya rejim Orde Baru tahun 1998, meski dilarang membuat siaran berita dan makanya harus merelay siaran berita RRI, beberapa stasiun radio telah berani menyiarkan talkback radio dengan menyiarkan siaran langsung di tempat (on the spot reporting) tentang penyerangan kantor PDI pada 27 Juli 1998 di Jakarta. Bahkan beberapa radio di Jakarta dan Bandung menurut Krishna Sen (2000: 
117) secara terang-terangan menyerukan dukungan kepada gerakan aksi demontrasi maha-siswa menggulingkan kekuasaan Soeharta. Radio, makanya papar Krishna Sen (2000:118) menjadi aktor penting dalam proses demokratisasi nasional; sumber opini publik yang beraneka ragam dan lokalitas serta sebagai alat bagi aktor politik untuk menjangkau penentu suara yang beraneka ragam. Radio talk juga mempengaruhi proses transisi politik kepada multi partai di negara Uganda (Christine Nabunya: 2009; 120).

Program siaran "Citra Publika" radio Citra FM. Kota Malang merupakan program siaran utama sejak tahun 2004 yang dirancang sebagai ruang publik bagi pendengar untuk menyampaikan keluhan sekitar layanan dan prasarana publik dan permasalahan publik lainnya. Dengan motto Malang News Channel, Radio berita pertama Kota Malang ini didirikan meniru kisah sukses Radio berita Suara Surabaya yang didirikan pada tahun 1985. Sama seperti warga Kota Surabaya yang selalu aktif memantau kejadian sosial politik dan prasarana publik di lingkungan serta melaporkannya ke Radio SS layaknya seorang reporter, warga Kota Malang juga diharapkan dapat secara aktif melaporkan kejadian-kejadian yang mengganggu kepentingan bersama serta melaporkannya lewat Citra Publika Radio Citra FM. Di sini tempat bertumbuhkembang potensi reporter warga yang nanti pada gilirannya akan melahirkan warga yang selalu aktif (active citizenship) memantau kinerja penyelenggaraan kehidupan publik.

Dengan demikian dapat dikatakan bahwa para warga masyarakat yang terlibat dalam proses pemberitaan baik di Andalus FM, dan Citra FM merupakan sekolompok warga yang peduli kepada lingkungan sekitar, bertanggungjawab terhadap diri sendiri dan orang lain serta ingin melihat bahwa semua penyelenggaraan layanan publik terlaksana demi kepentingan masyarakat bersama. Mereka menganggap keberadaan ruang berekspresi di media tersebut sebagai sarana untuk memperluas kepedulian serta mengajak warga lain untuk ikut berpartisipasi dalam menyelenggarakan kehidupan bersama. Mereka yakin bahwa bahwa penyelenggaraan kehidupan berbangsa dan bernegara ini tidak akan dapat lancar tanpa keikutsertaan mereka dalam menuntunt dan mendesak akuntabilitas para penyelenggara negara dalam menyediakan berbagaia layanan publik. Kewargaan aktif ini disulut dan dipicu oleh adanya ruang bereskpresi yang disediakan media tersebut. Dengan ruang publik yang telah disediakan tersebut aspirasi dan kepentingan mereka akan semakian digaungkan. Dengan demikian identitas sebagai warga negara yang memiliki hak-hak dan tanggungjawab menjadi perasaan kolektif sebagai dasar untuk mendesakkan kepentingan bersama kepada para penyedia layanan publik. Singkat kata, media massa telah ikut membantu menumbuhkembangkan identitas kolektif kewargaan aktif sehingga mampu mendorong mereka untuk selalu berpartisipasi secara aktif dalam proses pembuatan keputusan publik.

\section{Tinjauan Pustaka}

Media sebagai wahana demokrasi, dengan demikian, tak ubahnya sebuah kendaraan untuk melanggengkan kepentingan bisnis media dan sarana menangguk keuntungan belaka. Idealisme pers nasional sebagai tiang penyanggah demokrasi keempat (the fourth pillar of democracy) makanya akan sulit terwujud dalam setting media yang tunduk pada rezim pasar. Kepentingan publik pada informasi yang akurat, objektif, netral dan berimbang yang bertujuan untuk mencerdaskan dan mencerahkan warga 
negara (citizen) lenyap begitu saja ditelan hingar-bingar mesin-mesin raksasa kapitalis media. Demikian juga dengan fungsi kontrol sosial pers yang bermuara pada pengawasan terhadap penguasa politik dan pengusaha ekonomi akan kian melemah digerus oleh menguatnya daya dorong memenuhi ekonomi politik media kapitalis. Dengan kata lain, liberalisasi media akan mengubah karakter jurnalistik dan substansi isi media kepada kepentingan pasar. Kinerja media, menurut Croteau (2001: 20) akan semakin menjauh dari melayani dan memenuhi kepentingan publik sebab semua operasional media tidak dikelola sebagai sebagai ruang publik (public sphere); sebuah ruang sosial yang memungkinkan terjadinya perdebatan publik. Menurut Croteau (2001: 37), media massa sekarang menempatkan public atau audience semata-mata sebagai consumer bukan warga negara (citizens). Tujuan utama media adalah genarate profits for owners and stockholders. Kemudian mendorong khalayak untuk enjoy themselves, view ads, and buy product. Karena itu apa yang dianggap menarik bagi publik oleh media, adalah apapun yang populer di masyarakat. Dengan demikian tujuan ideal media untuk promote active citizenship via information, education and social integration, tenggelam dengan gelombang komersialisasi dan liberalisasi. Jadinya ukuran keberhasilan media semata-mata adalah profit, bukan serving the public interest.

Akibat langsung dari komersialisasi media adalah melemahnya proses demokrasi serta kian tidak berdayanya masyarakat secara politik seperti yang disebut oleh Herbert J Gans (2003;15) sebagai political disempowerment. Hal ini karena kekuatan pasar, lanjut Croteau (2001: 21-23) memiliki beberapa kelemahan. Pertama, pasar tidak demokratis sebab pasar tidak sesuai dengan asumsi dasar demokrasi bahwa masing-masing individu memiliki hak-hak yang sama. Padahal hukum pasar adalah; "the more money you have, the more influence you have in the marketplace". Kedua, pasar akan semakin melanggengkan ketimpangan sosial. Ketiga, pasar tidak bermoral sebab kepentingan utamanya adalah menjual dan memenuhi tuntutan tanpa mempedulikan adakah produk tersebut bermanfaat dan berbahaya terhadap masyarakat. Keempat, pasar tidak selamanya bisa memenuhi kepentingan sosial. Kelima, pasar tidak mampu memenuhi kepentingan demokrasi.

Lokus fungsi demokratisasi pers terletak pada sejauhmana pers telah mampu menjadi sebuah ruang publik (public sphere) ; sebuah ruang yang terbebas dari dominasi politik penguasa dan kepentingan ekonomi pengusaha yang memungkinkan terjadi perbincangan publik yang rasional tentang isu-isu publik yang mempengarahi kehidupan masyarakat. Ruang ini menurut Brian Mc Nair (1999;20-21) merupakan esensi lembaga komunikasi substansial masyarakat yang memungkinkan disebarluaskannya fakta dan pendapat. Di ruang yang terdiri dari stok pengetahuan publik ini dapat dibangun dasar tindakan politik kolektif masyarakat. Pada ruang ini pula, menurut Croteau (2001: 20) dimungkinkan dibentuknya sebuah ruang sosial untuk terjadinya perbincangan publik secara bebas tanpa pembatasan. Sebagai ruang publik masyarakat, maka jurnalisme hadir untuk membangun kewargaan (citizenship); untuk memenuhi hak-hak warga sebab jutaan orang terberdayakan oleh arus informasi bebas. Lebih lanjut, Bill Kovach dan Tom Rosenstiel (2004:6 ) menyatakan bahwa tugas utama wartawan yakni menyediakan informasi yang dibutuhkan warga agar mereka bisa hidup merdeka dan mengatur diri mereka. Agar tugas mulia ini bisa dilakukan wartawan, Bill Kovach menyarankan sembilan hal 
yang mesti dipegang teguh dalam melaksanakan kegiatan jurnalistik mereka. Sembilan hal tersebut adalah:

1) Kewajiban pertama jurnalisme adalah pada kebenaran;

2) Loyalitas pertama jurnalisme adalah memenuhi hak mengetahui warga;

3) Intisari jurnalisme adalah disiplin dalam verifikasi;

4) Para wartawan harus menjaga independensi terhadap sumber berita;

5) Jurnalisme harus berfungsi sebagai pemantau kekuasaan;

6) Jurnalisme harus menyediakan forum publik untuk kritik maupun dukungan warga. (7) Jurnalisme harus berupaya membuat hal-hal penting menarik dan relevan;

7) Jurnalisme harus menjaga agar berita komprehensif dan proporsional;

8) Para praktisinya harus diperbolehkan mengikuti nurani mereka;

Dengan nada sama, Brian Mc Nair (1999;22-23) menyatakan demokrasi mengasumsikan adanya sebuah sistem yang terbuka yang memungkinkan warga untuk berpartisipasi. Untuk itu, mereka harus diberikan akses yang memadai terhadap media dan jaringan informasi yang memungkinkan terjadinya advokasi. Demokrasi juga mengasumsikan khalayak dididik dan diberi pengetahuan yang cukup sehingga mereka dapat membuat keputusan rasional dan secara efektif menggunakan informasi yang tersebarluaskan dalam ruang publik. Lebih lanjut Mc Nair (1999;26) mengajukan beberapa persyaratan yang harus dipenuhi media demi memperlancara proses demokratisasi. Hal tersebut adalah ;

a. memberikan informasi kepada masyarakat tentang peristiwa yang terjadi di sekitar mereka. b. Mendidik warga tentang arti dan nilai penting dari fakta lewat tetap menjaga objektivitas peristiwa yang diliput sebagai konsekwensi dari fungsi pendidik yang meniscayakan kemandirian profesional dari isu yang sedang diangkat.

c. Menyediakan sebuah platform bagi terlaksananya sebuah perbincangan publik tentang politik, mempermudah terbentuknya pendapat umum serta menyebarluaskan opini publik tersebut.

d. Mengaplikasikan fungsi sebagai anjing penjaga (watchdog role) dengan mempublikasikan kinerja lembaga politik dan pemerintah dengan melakukan investigasi terhadap penyimpangan yang dilakukan. Opini publik hanya akan bermakna dalam realitas politik ketika perilaku para penyelenggara kekuasaan diungkap kepada publik sehingga publik dapat menuntut pertanggungjawaban.

e. Berfungsi sebagai saluran untuk advokasi pendapat politik tertentu.

Talkback radio dapat dapat dimaknai sebagai program siaran interaktif yang menggambarkan adanya interaksi antara pendengar dan penyiar yang disertai ada atau tidak adanya nara sumber di studio. Program ini inherent dengan media radio yang memang bercirikan utama interaktivitas. Karakter mencolok program ini adalah kegiatan jurnalistiknya; berbagi informasi dan gagasan aktual oleh pendengar. Hal ini menurut Errol Jonathans dalam Stiftung (2000:39) dapat disebut sebagai jurnalisme interaktif yang memberikan peluang kepada pendengar terlibat aktif dalam proses siaran informasi. Pendengar tidak lagi sebagai penikmat tetapi 
mengambil peran aktif dalam memberikan informasi layaknya reporter.

Mengenai definisi 'talk radio' dan 'talkback' ada banyak pendapat mengenai hal tersebut. Carolyne Lee (2007: 4) dengan mengutip pendapat Jon Faine, menjelaskan perbedaan antara 'talk radio' dan 'talkback'. Talkradio berarti program siaran dimana penyiar melibatkan nara sumber tamu di studio tanpa melibatkan melibatkan pendengar berinteraksi lewat telepon. Sedangkan talkback radio adalah program siaran yang mengajak pendengar terlibat berinteraksi lewat jaringan telepon dengan penyiar di studio baik disertai dengan atau tanpa nara sumber tamu di studio. Lee memandang bahwa istilah talkback radio merujuk kepada setiap program siaran interaktif yang memungkinkan pendengar terlibat aktif menyampaikan komentar permasalahan publik, wawancara yang telah dirancang dan disiapkan penyiar. Pendengar dapat menelpon, mengirim pesan singkat atau surat elektronik kepada program siaran menyampaikan pendapat, komentar, atau informasi yang mereka peroleh. Talkback radio menurut Jacqui Ewart adalah program siaran radio yang mengundang pendengar berdiskusi lewat saluran telepon dengan penyiar radio tentang perma-salahan yang mereka pilih dan tetapkan atau sebagai tanggapan tentang tema yang telah ditetapkan oleh penyiar radio yang biasanya berkenaan dengan pemberitaan yang sedang menghangat di masyarakat.

\section{Metode Penelitian}

Penelitian yang menggunakan pendekatan kualitatif ini menggali data penelitian lewat pengamatan dan wawancara mendalam dengan para awak redaksi Radio Citra FM. Mereka adalah Sudarmaji, Direktur Radio yang juga merangkap sebagai Penanggungjawab Bidang Pemberitaan, Aris Tri Johansyah, staf Marketing, Rio Despantara, penyiar dan Remmy Dianing Astuti, penyiar. Informan lain adalah Esti Winarno, mantan penyiar Citra FM yang sekarang bergabung RRI Malang dan Syahrotsa Rahmania, pengasuh program siaran 'Kata Kota Kita'. Penelurusan terhadap data sekunder juga dilakukan untuk menambah dan memperkaya data hasil penelitian.

\section{Temuan \& Hasil Penelitian}

Berdiri pada tanggal 5 Januari 2004, Radio yang bernama awal Citra Pro 3 bertempat di kawasan kompleks Radio Republik Indonesia Cabang Pratama Malang di Jalan Candi Panggung 18 Malang. Semua fasilitas penyiaran mulai alat siaran hingga pemancar dan ruang siaran serta ruang administrasi merupakan milik RRI. Ini merupakan kerjasama antara manajemen Citra Pro 3 dengan pihak RRI Malang yang ketika itu dikepalai oleh M Natsir Asfa. Salah satu butir perjanjian tersebut adalah Citra diberi hak untuk menggunakan frekuensi Programa 3 di saluran 105 FM. Pada saat awal pendiriannya, Citra telah mendeklarasikan dirinya sebagai radio berita. Ini bisa dilihat dari motto MNC ; Malang News Channel (Saluran berita di Malang). Citra merupakan radio pemberitaan pertama di Malang Raya. Pada saat itu, dari puluhan stasiun radio di Malang Raya baik yang menjadi anggota Persatuan Radio Siaran Swasta Nasional Indonesia PRSSNI ( Malang Raya) sebanyak 14 radio stasiun maupun non PRSSNI semuanya berorietasi pada radio hiburan dan informasi. Setelah 2 tahun, tepatnya pada tahun 2006 Citra berpindah ke lokasi baru di kawasan Claket tepat di depan Rumah Sakit Umum Daerah Saiful Anwar di Jln Hasanuddin I A Malang.

Radio Citra bersiaran satu minggu penuh alias 7 hari dalam satu minggu dengan durasi siaran sebanyak 18,5 jam setiap hari yang dimulai dari jam 05:30 WIB hingga 24:00 WIB. Format siaran 
yang ditampilkan adalah siaran berita dan dialog (news dan talk radio). Meski demikian, ranah hiburan tetap tersaji dengan format musik yang mengetengahkan lagu easy listening dengan adult contemporary dengan komposisi Indonesia Populer 60 persen dan Barat populer 40 persen. Sajian ini tepat tersaji secara proporsional. Radio yang bermottokan 'The Real One And Only News Channel In Malang' ini bertekad untuk memuaskan pen-dengarnya dengan sajian-sajian informasi yang akurat, terkini baik melalui laporan on the spot maupun dari studio. Tak hanya di situ, radio yang memiliki call station 'mitra pendengar' ini juga memberikan tempat yang seluas-luasnya bagi informasi yang disampaikan oleh pendengar sendiri. Interaksi terjadi setiap saat di Citra Malang. Di antara program-program tersebut ada yang memang dilahirkan untuk menjadi program highlight, dan ada juga yang ternyata dipilih oleh Mitra Pendengar kami sebagai program favorit. Citra Publika, adalah core program yang hadir setiap hari pagi mulai pukul o8.0012.00, siang mulai pukul 13.00-16.00, dan edisi malam pukul 18.00-19.00. Dalam program ini, penyiar menampung berbagai persoalan, khususnya yang berkaitan dengan public services dan gagasan-gagasan yang murni datang dari warga. Kami juga berusaha menyambungkan setiap persoalan dengan pihak yang relevan dan paling berkompeten untuk menyelesaikan problem tersebut, baik dari institusi pemerintah, badan usaha, atau bahkan pihak yang berwenang dan berwajib.

Berkaitan dengan informasi, ada sejumlah program news mulai Citra Pagi yang pukul 05.30, hingga Citra Malam pukul 22.30. Progaram siaran laporan dari reporter sepanjang pagi dirangkum dalam Citra Siang yang ditayangkan pukul 12.00. Sementara laporan terkini reporter sepanjang siang dirangkum dalam Citra Sore, pukul 16.00-17.00 WIB. Selain itu, ada program Citra Opini, yang disiarkan pukul 19.00 setiap hari. Program ini biasanya menyuguhkan obrolan tematis yang diusung oleh narasumber terpercaya serta mengundang gagasan-gagasan dari Mitra Pendengar. Pakar juga ikut urun bicara untuk memberikan pendapatnya yang shahih. Dan tak bisa dilewatkan, program Bingkai berisi feature dan current affairs selama 5 sampai 7 menit per episodenya setiap hari pukul 09.45 dan 14.15 yang mengupas persoalan yang ada di tengah masyarakat secara tuntas, dengan narasi dan insert yang komprehensif.

Masih ada beberapa program seperti Citra Polisi mengupas informasi dialog interaktif bersama kalangan intitusi kepolisian Malang Raya setiap hari Sabtu pukul 09.00-10.00. Citra Wanita yang khusus mengupas problem perempuan disiarkan setiap sabtu pukul 12.00 sampai 13.0o WIB. Ada juga program musik Jazzy News setiap hari Senin, Rabu, Jumat pukul 20.00-21.00 yang meng-hadirkan seputar lagu Jazz mancanegara dan lokal. Tidak hanya itu setiap minggu malam pukul 22.30-24.0o WIB, ada sajian musik jazz anda dengan Jazz On Sunday. Ada pula program Country Traffic setiap hari Selasa pukul 20.00-21.00. Bagi penggemar musik lawas, dan bagi pecinta musik Rock, ada program Rock \& Story hadir setiap Sabtu pukul 21.00-24.00 WIB. Nah, bagi penggemar olahraga, ada program hot sport yang setiap saat dan flash news berita olahraga mulai pukul o8.oo. untuk fans bola mania atau Aremania, ada program Arema Corner yang disiarkan setiap Senin hingga Jumat pukul 21.00-23.00 WIB.

Citra Publika, adalah core program siaran Citra FM Program ini disiarkan setiap hari pagi mulai pukul 08.00-12.00, siang mulai pukul 13.00- 
16.0o, dan edisi malam pukul 18.0019.00. Program ini dirancang dengan maksud meningkatkan peran dan partisipasi warga masyarakat untuk menyampaikan dan melaporkan semua hal berkaitan dengan rendahnya kualitas layanan publik yang diselenggarakan baik oleh pemerintah maupun pihak swasta. Juga warga lewat program ini dapat melaporkan apa yang terjadi di lingkungan warga berkaitan dengan arus lalu lintas, layanan publik berupa listrik, dan jaringan air minum. Pihak Citra dalam program ini, akan langsung menindaklanjuti semua informasi yang dilaporkan masyarakat dengan menghubungi pihak terkait yang berwenang baik dengan maksud sekedar mengklarifikasi atau menyampaikan informasi tersebut. Lewat acara ini, Radio Citra memposisikan diri sebagai mediator langsung antara warga masyarakat dengan pihak yang bersangkutan. Pendengar dapat menyampaikan informasi lewat layanan SMS dan telepon selama 18,5 jam.

Edukasi pendengar untuk peduli dan berpartisipasi aktif dalam program siaran dengan menyampaikan keluhan layanan publik memang memerlukan proses waktu yang panjang. Setelah 5 tahun mengudara, toh antusiasme warga untuk berpartisipasi dalam program siaran dirasa belum mampu memenuhi keinginan manajemen radio. Sudarmaji yang ditugasi sebagai penanggungjawab pemberitaan mengeluhkan rendahnya partisipasi warga Malang untuk melaporkan keluhan layanan publik dan informasi publik. Bahkan untuk program Arema Corner yang dikhususkan untuk fans Aremania lanjut Sudarmaji lalu lintas hubungan telepon dari penggemar Arema juga tidak bisa memenuhi harapan manajemen radio. Keadaan ini lanjutnya bisa dimengerti karena ada radio pesaing yang menyajikan siaran yang sama. Sudarmaji akhirnya menyimpulkan bahwa warga Malang Raya berbeda dengan warga Surabaya. Lewat Radio Suara Surabaya FM, warga kota Surabaya telah menjadi aktif terlibat dalam mengawasi penyediaan layanan publik. Penerapan idealisme jurnalisme radio yang tidak sebanding dengan keuntungan finansial ini mengakibatkan konflik di internal manajemen Citra FM yang berakhir dengan penutupan operasi siaran.

\section{Pembahasan Hasil Penelitian.}

Sebagai radio berita, Radio Citra ingin memposisikan diri sebagai satusatunya radio yang mendedikasikan sebagai jam siarannya untuk interaksi dengan pendengar untuk berbagi informasi dan solusi. Ini peluang bisnis yang diyakini mengingat kota Surabaya juga memiliki radio jenis ini. Citra FM ingin meniru kisah sukses radio Suara Surabaya yang didirikan 25 tahun silam tepatnya tahun 1985. SS menerapkan konsep jurnalis interaktif; warga pendengar dianggap sebagai reporter yang peduli dan aktif dalam permasalahan publik. Masalah yang dilaporkan sekitar arus transportasi, layanan publik serta masalah publik yang menyangkut hajat hidup orang kebanyakan. SS beranggapan bahwa pendengar reporter telah dewasa dan kritis terhadap permasalahan publik. Kepedulian dan daya kritis ini kemudian disalurkan lewat program siaran Kelana Kota yang merupakan program utama. Begitu populernya program ini di benak pendengarnya sehingga mengalahkan ketenaran nama stasiun radio. Kalau sudah demikian, radio tidak hanya sebagai sarana mendapatkan hiburan, tempat berbagi salam kepada rekan dan sahabat seperti yang jamak terjadi pada hampir semua stasiun radio. Pada kenyataannya, radio juga sarana berbagi informasi, dan memperoleh informasi permasalahan publik. Tidak heran, kalau radio interaktif seperti ini telah mampu membantu polisi memberikan informasi sekitar kejahatan yang seperti pencurian mobil atau 
perampokan. Hal ini mengingat semua reporter warga adalah orang mobil yang selalu bergerak dengan kendaraan roda empat mereka saat berangkat atau bepergian ke tempat kerja atau keluar kota.

Bertujuan untuk menggerakkan warga Kota Malang untuk menjadi jurnalis warga, Radio Citra mengikuti kisah sukses Radio Suara Surabaya FM dengan menggelar program siaran Citra Publika. Program ini dapat dianggap sebagai ruang publik; tempat netral terbebas dari kepentingan ekonomi dan politik; wadah mendiskusikan permasalahan publik sebagai kontrol terhadap kuasa ekonomi dan politik serta mendesakkan agenda publik kepada para penyelenggara kehidupan publik. Berdasarkan pemikiran ini, Citra merancang program ini sedemikian rupa sehingga tidak terjadi saling menghujat dan menista antara pihak-pihak yang bermasalah. Kode etik jurnalistik yang menuntut keberimbangan dan akurasi data beserta usulan solusi dari warga selalu ditekankan oleh setiap penyiar Radio Citra. Citra lewat acara ini juga ingin mendidik para jurnalis warga agar menyampaikan data faktual, dengan tetap menerapkan rumus $5 \mathrm{~W} 1 \mathrm{H}$ sebagai patokan baku dalam kegiatan jurnalistik. Nah, agar terjadi keberimbangan informasi, Citra selalu berusaha untuk klarifikasi dan konfirmasi kepada pihak terkait. Ini menjadi tugas berat para Gatekeeper untuk melakukan hal tersebut.

Konsep mengenai public sphere dipicu pertama kali oleh tulisan Jurgen Habermas yang berjudul The Public Sphere pada tahun 1962. Dalam esai tersebut, menurut Barret dalam Oliver Boyd-Barret (1995:230-231) Habermas mengatakan tentang praktik pertukaran gagasan dan diskusi terbuka berkaitan dengan isu-isu sosial yang memungkinkan terwujudnya sebuah a sense of the public (watak kepublikan) bukan sebagai sebuah prinsip yang abstrak tapi sebagai $a$ culturally embedded social practice (praktik sosial budaya yang melekat). Praktik sosial yang terbuka, bebas dari sensor dan dominasi inilah yang disebutnya sebagai "public sphere'. Yaitu semua wilayah yang memungkinkan kehidupan sosial manusia membentuk opini publik yang relatif bebas. Penekanannya mengenai pembentukan kepekaan kemasyarakatan (sense of public), sebagai praktek sosial yang melekat secara budaya. Orang-orang yang terlibat di dalam percakapan public sphere adalah orang-orang privat, bukan orang dengan kepentingan bisnis atau profesional, bukan pejabat atau politikus, yang memiliki kebebasan dalam menyatakan pendapatnya.

Dengan demikian laporan yang disampaikan pendengar akan selalu ditampung oleh gatekeeper selama masa jam siaran berlangsung. Laporan yang disiarkan kalau sedang berlangsung Citra Publika. Laporan yang masuk di luar jam siaran tetap ditampung dan akan dikonfirmasi dan klarifikasi oleh gatekeeper. Tergantung kepada derajat kepentingan dan kemendesakan infor-masi, klarifikasi ini akan dimintai konfirmasi yang ditayangkan secara on air. Radio Citra lewat program siaran ini ingin memposisikan diri sebagai radio penyampai informasi, klarifikasi dan konfirmasi untuk menjadi kepercayaan pendengar. Lewat mekanisme ini diharapan lembaga penyedia layanan publik dapat menindaklanjuti laporan yang disampaikan lewat program siaran ini sehingga dengan demikian dapat memenuhi aspirasi masyarakat yang mengharapkan ketersediaan prasarana publik dan layanan publik yang profesional.

Berkenaan dengan mekanisme operasio-nal Citra Publika dalam 
menumbuh-kembangan kewargaan aktif

dapat dilihat dari gambar di bawah ini:

\section{Gambar 1: Operasional Siaran Citra Publik}

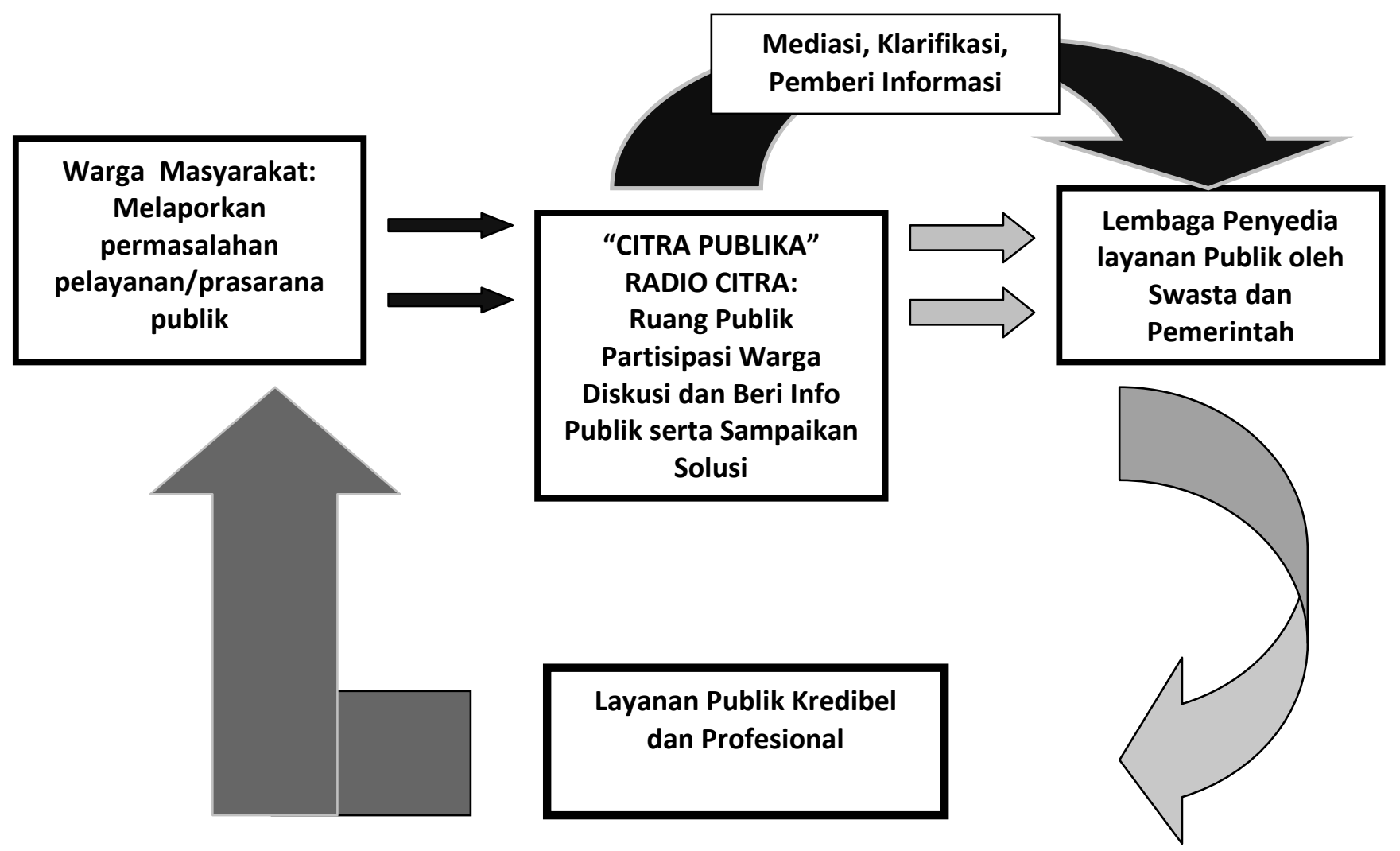

Radio Citra ingin memperantarai interaksi antara warga masyarakat dengan penyedia layanan publik yang selalu tidak menemukan titik temu atau tanpa tindak lanjut yang memuaskan warga. Meski sarana komunikasi telah disediakan oleh lembaga penyedia layanan publik, tapi tetap saja belum memuaskan sebab lambanya atau ketiadaan tindaklanut nyata dari lembaga yang bersangkutan. Kepercayaan reporter warga akan semakin meningkat ketika laporan yang disampaikan ditindaklanjuti oleh lembaga yang bersangkutan meskipun hanya sebatas informasi. Eskposure lembaga terkait lewat media siaran radio seperti ini juga diharapakan akan mampu mendidik warga yang lain untuk lebih berhati-hati. Tidak hanya itu, diharapkan eksposure seperti ini akan mampu mengontrol dan memperbaiki kinerja lembaga penyedia layanan publik. Sehingga dengan demikian akan memunculkan sikap kewargaan aktif warga masyarakat lainnya. Partisipasi warga yang selalu mengawasi perilaku penyelenggara kehidupan publik merupakan hal penting bagi berjalannya proses demokratisasi bangsa yang sedang berjalan saat ini.

Dari paparan diatas dapat disimpulkan bahwa Citra Publika dapat berfungsi sebagai ruang publik; tempat bertumbuhkembangnya jurnalis warga yang melaporkan peristiwa isu-isu dan pelayanan publik yang bermasalah. Proses pendidikan jurnalistik radio dan kewargaan aktif telah berlangsung dalam program siaran ini. Dari sinilah titik penting dari proses demokratisasi bangsa; sebuah proses penting untuk mewujudkan kesejahteraan rakyat bertumpu. Proses ini dapat dilihat dari gambar 2. 


\section{Gambar 2 : Proses Demokratisasi Lewat Citra Publik}
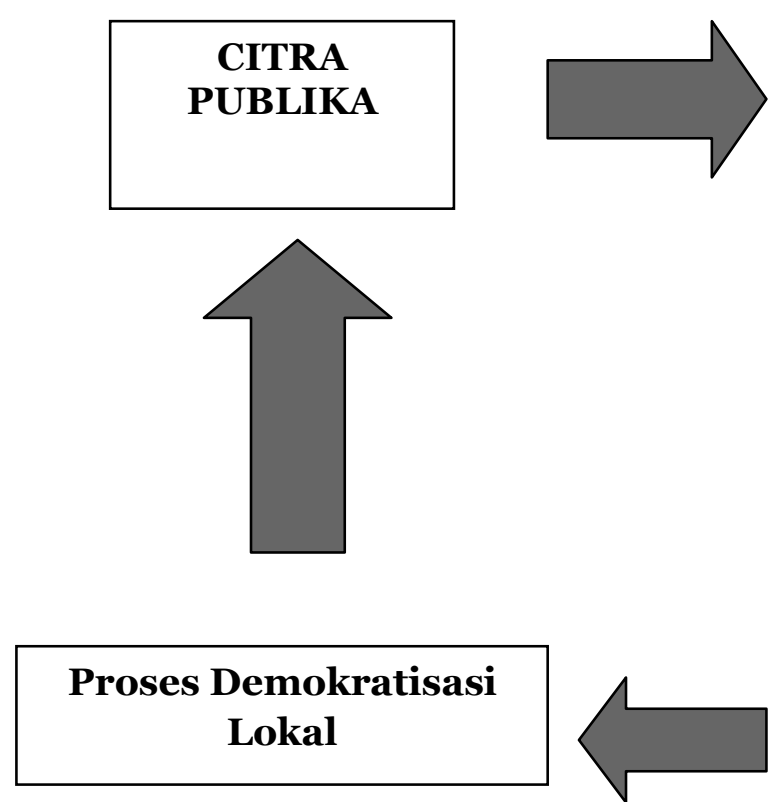

Ruang Publik Masyarakat:

1. Tampung \& Siarkan keluhan dan saran warga ttg isu-isu dan permaslahan publik

2. Lahirnya jurnalis warga sebab mereka diarahkan untuk laporkan data dan fakta akurat

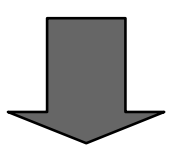

Kewargaan Aktif : warga peduli dan kritis terhadap masalah publik, mendesakkan agenda publik sebagai acuan dalam merancang kebijakan publik
Paparan ideal diatas meski demikian masih jauh dari kenyataan. Kendala yang dihadapi menurut Sudarmaji adalah rendahnya partisipasi warga dalam berinteraksi untuk melaporkan dan menyampakan keluhan berkaitan dengan prasarna publik. Rendahnya partisipasi warga ini memang diakui oleh penyiar Rio Despantara. Dalam kenyataan yang teramati memang demikian. Ini terutama terjadi saat siang hari. Terkadang nyaris tanpa ada warga yang menelpon ke studio. Sehingga penyiar bukannya berusaha untuk menyampaikan informasi dengan mengutip sumber koran yang ada tentang masalah publik. Sayangnya, justru penyiar memutar lagu-lagu yang justru bertentangan dengan misi utama berbagi informasi dan solusi. Seharusnya, misi ini tetap harus terlaksana dengan mengutip sumber-sumber informasi yang bisa dipercaya atau berusaha proaktif untuk menyampaikan agenda pemerintah lokal. Singkat kata yang berbagai informasi bukan hanya warga. Tapi penyiar yang bersangkutan juga harus membagikan info penting yang berkaitan dengan agenda publik lokal; isu-isu yang menyangkut permasalahan warga kebanyakan.

Hal lain yang menjadi kendala adalah rendahnya kesadaran para penyelenggara prasarana publik untuk menindaklanjuti laporan keluhan warga masyarakat. Redaksi Citra berharap besar bahwa para penyelenggara layanan publik mestinya menjadi informasi yang disiarkan sebagai masukan penting untuk memperbaiki kinerja mereka. Sehingga Citra tidak perlu bersusah payah untuk mengklarifikasi dan mengkonfirmasi tentang info yang disampaikan warga masyarakat. Kedua hal tersebut memang 
perlu waktu untuk menuntaskannya. Sebab usia Citra baru 5 tahun; merubah perilaku masyarakat dari apatisme kepada aktivisme memang memerlukan waktu panjang. Penerapan jurnalisme radio menurut Errol Jonathans (2006:101) tidak serta merta akan mendatangkan keuntungan finansial bagi manajemen radio. Secara logika, paparnya radio yang berjurnalisme akan mampu menjaring pendengar yang banyak dengan sajian program interaktif dan informasi yang aktual. Dengan demikian, maka, iklan akan berdatangan. Tapi jurnalisme ini bukan obat perangsang mujarab yang akan menyembuhkan penyakit sepinya pendengar dengan seketika. Hal ini lanjutnya akan memerlukan proses waktu yang panjang. Suara Surabaya FM memerlukan waktu 25 tahun untuk menikmati sukses bisnis yang dinikmati saat ini.

Seharusnya Citra FM dapat meraih sukses kalau manajemen asalkan manajemen dapat menahan diri dan lebih ulet untuk terus menerus melakukan kegiatan siaran. Hal ini karena sebelum Citra FM berdiri telah ada program talkback radio "Kata Kota Kita" yang disiarkan Andalus FM. 'Kata Kota Kita' yang diluncurkan pada tahun 1998 telah mampu menggairahkan pendengar untuk peduli dan melakukan kontrol terhadap layanan publik. Begitu fakta keluhan layanan publik disampaikan pendengar, host penyiar lantas mengkonfirmasi kepada pihak terkait untuk mendapatkan respons perbaikan. Antusiasme warga menguat untuk terlibat dalam program ini. Tidak heran, kalau tahun 2000 dan 2002, program siaran ini mendapatkan penghargaan dari UNESCO atas kerja keras ini. Organisasi internasional ini memberikan hibah peralatan teknis radio dan pelatihan keradioan di Jakarta sebagai wujud apresiasi atas prestasi ini. Meski demikian, subtansi dan semangat yang dihembuskan oleh program tersebut hanya mengudara hingga penghujung tahun 2006 akibat konflik antara host program dengan manajemen radio.

Talkback radio dapat berperan penting dalam proses demokrasi local dan menguatkan lokalitas. Sebuah penelitian tentang khalayak talkback radio di Australia yang didanai Reporting Diversity Project menurut Jacqui Ewart (tanpa tahun: 90) telah menemukan beberapa hal sebagai berikut : bahwa program ini telah menciptakan rasa kebersaam antara warga masyarakat (a sense of community) bai khalayak dan sebuah peluang bagi terbangunakan jaringan social di masyarakat; menyediakan kesempatan menjalin pertemanan bagi mereka yang merasa terisolasi (Provides company for people who may otherwise feel isolated) ; menyediakan sebuah bentuk terapi bagai sebagai khalayak lewat penyajian informasi dan nasehat tentang isu-isu serta menyajikan akses kepada pengalaman dan suara dari warga masyarakat yang lain; menyajikan informasi lokal yang bisa disediakan oleh media yang lain; memberikan akses bagi pendengar kepada ruang publik serta peluang bagi mereka untuk terlibat dalam proses demokrasi lewat interaksi mereka dengan para pejabat dan politisi lokal secara langsung; menyediakan peluang bagi warga kebanyakan untuk menyampaikan informasi dan berita, mengkoreksi layanan publik dan memberikan kontribusi agenda berita terhangat; menyediakan sebuah ruang bagi berkembangnya beberapa solusi terhadap permasalahan yang sedang dihadapi; memberikan ruang bagi warga masyarakat untuk melakukan lobi tentang isu-isu tertentu dan memberikan sumber berita bagi penyiar radio; membuka ruang lebar untuk penyampaian pendapat, suara dan gagasan yang berbeda yang selama ini kurang mendapatkan kesempatan akes untuk disuarakan kepada publik secara terbuka. Proses demokratisasi lokal, peran talkback radio menurut Richard 
Fitzgerald (2007:90) adalah mendidik masyarakat terhadap kebijakan pemerintah. Peran ini lantas harus ditindaklanjuti dengan peran pemberian umpan balik dari warga tentang kebijakan tersebut.

\section{Simpulan Dan Saran}

Berdasarkan paparan di atas dapat disimpulkan beberapa hal :

1. Program siaran Citra Publik merupakan ruang publik ; ruang netral terbebas dari tekanan ekonomi politik sehingga warga masyarakat dapat menyampaikan keluhan dan saran sekitar permasalahan publik secara bebas.

2. Citra Publika dapat berfungsi secara efektif sebagai sarana mendidik reporter warga sebab mereka akan diarahkan oleh penyiar untuk menyampaikan fakta akurat beserta solusi dari permasalahan tersebut. Rumus $5 \mathrm{~W} 1 \mathrm{H}$ yang menjadi patokan baku dalam kegiatan jurnalistik tetap diterapkan. Nah, untuk menjaga keberimbangan informasi pihak Citra selalu berusaha lewat gatekeeper untuk mengkonfirmasi dan mengklarifikasi informasi tersebut.

3. Citra Publik dapat menumbuhkembangkan sikap kewargaan aktif; sikap peduli dan kritis terhadap isu-isu dan permasalahan publik; sikap yang perlu dilembagakan untuk mempermulus proses demokratisasi lokal dan nasional.

4. Kendala yang dihadapi redaksi Citra adalah rendahnya partisipasi warga dalam menyampaikan informasi publik dan minimnya kesadaran para penyelenggara kehidupan publik untuk menindaklanjuti keluhan tersebut.
5. Manejemen radio tidak memiliki komitmen kuat bahwa menerapkan jurnalisme radio merupakan proses dan memerlukan waktu yang panjang untuk mendidik warga agar aktif peduli terhadap lingkungan mereka.

Berdasarkan hal tersebut diatas dapat disampaikan beberapa saran:

1. Penyiar harus memanfaatkan kekosongan interaksi/laporan informasi dari warga dengan mengutip sumber informasi yang terpercaya. Atau selalu berusaha proaktif untuk mencari sumber-sumber dari penyelenggara kehidupan publik yang bermanfaat bagi warga masyarakat.

2. Perlu digencarkan upaya promosi program siaran ini dengan menjalin kerjasama dengan lembaga pendidikan menengah dan tinggi. Bekerjasama dengan lembaga pendidikan menengah atas perlu dilakukan untuk mendukung mata pelajaran Pendidikan Kewarganegaraan. Untuk perguruan tinggi, juga demikian. Tapi hal ini mesti mendapatkan tekanan yang lebih berat.

3. Perlu dilakukan pertemuan berkala untuk para jurnalis warga demi memotivasi mereka dan menyegarkan dan memperluas perspektif mereka untuk terus memajukan proses demokrasi yang sedang berjalan saat ini.

4. Manejemen radio harus memiliki komitmen kuat bahwa menerapkan jurnalisme radio merupakan proses dan memerlukan waktu yang panjang untuk mendidik warga agar aktif peduli terhadap lingkungan mereka. 


\section{DAFTAR PUSTAKA}

Barret, Boyd, Oliver \& Newbod, Chris (ed). 1995. An Approach to Media: A Reader, Arnold, New York: Arnold

Croteau, David \& Hoynes, William. 2001. The Business Of Media: Corporate Media and The Public Interest, California: Pine Forge Press

Ewart, Jacqui. Tanpa tahun. Talkback Radio: An emotional homeland and heartland: A study of some Australian talkback radio audiences, diunduh dari www.reportingdiversity.org.au/do cs/Talkbackradioreport.pdf

Fitzgerald, Richard. 2007. The Role of Talkback Radio in Hong Kong and Singapore: An Initial Exploration. Media International Australia. No. 124 - August 2007 diunduh dari https://www.academia.edu/301101/ An initial exploration of the role of Talkback Radio in Hong Ko $\underline{n g}$ and Singapore tanggal 26 September 2014

Gans, Robert J. 2003. Democracy and The News. New York: Oxford University Press

Jonathans, Errol. 2006. Socrates di Udara: Esai-Esai Jagad Keradioan. Surabaya: Gong Plus dan Suara Surabaya

Kovach, Bill \& Rosenstiel, Tom. 2003. Sembilan Elemen Jurnalisme, Jakarta: Pantau
Lee, Carolyne. 2007. 'Mornings with Radio 774: Can John Howard's Medium of Choice Enhance Public Sphere Activity?'. Media International Australia, diunduh dari https://dtl.unimelb.edu.au/ researchfileg9116.pdf.

McChesney, Robert W, 2000, Rich Media, Poor Democracy: Communication in Dubious Politics, New York: The New Press

McNair, Brian. 1999. An Introduction to Political Communication. London: Routledge

McQuail, Dennis. 1992. Media Performance: Mass Communication and The Public Interest. London: Sage Publication

McQuail, Dennis. 200o. Mass Communication Theory. London: Sage Publication

Nabunya, Christine. 2009. The Role Radio Talk Shows In The Transition To Multiparty Politics And Democracy In Uganda: A Case Study, Master's Thesis Department of Journalism and Mass Communication, International School of Social Sciences, University Of Tampere diunduh dari http://tampub.uta.fi/bitstream/han dle/10024/81328/gradu04101.pdf?s equence $=1$ tanggal 26 September 2014 
Rochmad Effendy, Program Siaran Interaktif (Talk Back Radio) Sebagai Ruang Publik Masyarakat Untuk Mengembangkan Demokrasi Lokal: Studi Pada Program ”Citra Publika” Radio Citra 87,9 FM Kota Malang.

Stiftung, Nauman, Friedrich, 2000. Poltik dan Radio: Panduan Bagi Jurnalis Radio, Jakarta: Friedrich Nauman Stiftung

Sen, Krishna, \& Hill, David, 200o.Media, Budaya dan Politik di Indonesia, Jakarta: Institut Arus Informasi 
Jurnal komunikasi, Volume 9, Nomor 1, Oktober 2014 